\title{
Correction: Role of combining anticoagulant and antiplatelet agents in COVID-19 treatment: a rapid review
}

Matli K, Farah R, Maalouf M, et al. Role of combining anticoagulant and antiplatelet agents in COVID-19 treatment: a rapid review. Open Heart 2021;8:e001628. doi:10.1136/ openhrt-2021-001628

Since the publication of this article, author Nibal Chamoun's affiliation has been corrected to 'School of Pharmacy, Lebanese American University, Byblos, Lebanon'.

Open access This is an open access article distributed in accordance with the Creative Commons Attribution Non Commercial (CC BY-NC 4.0) license, which permits others to distribute, remix, adapt, build upon this work non-commercially, and license their derivative works on different terms, provided the original work is properly cited, appropriate credit is given, any changes made indicated, and the use is non-commercial. See: http://creativecommons.org/licenses/by-nc/4.0/.

C Author(s) (or their employer(s)) 2021. Re-use permitted under CC BY-NC. No commercial re-use. See rights and permissions. Published by BMJ.

Open Heart 2021;8:e001628corr1. doi:10.1136/openhrt-2021-001628corr1

(A) Check for updates 